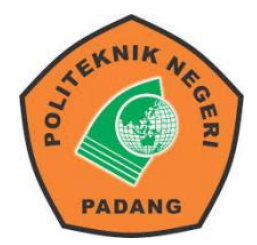

\author{
Jurnal IImiah Rekayasa Sipil \\ Available online at : http://ejournal2.pnp.ac.id/index.php/jirs/ \\ Terakreditasi SINTA Peringkat 5
}

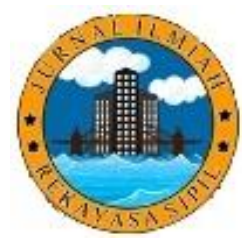

\title{
Analisis Kenyamanan Klimatik, Fisik Dan Visual Di Jalur Pedestrian Kota Padang (Studi Kasus: Jalan Ratulangi - Jalan Permindo)
}

\author{
${ }^{1}$ Angelalia Roza, ${ }^{2}$ Sandri Artika Suri \\ 1, 2Jurusan Teknik Sipil, Fakultas Teknik, Institut Teknologi Padang \\ 1angelaliaroza@gmail.com,
}

\begin{abstract}
The pedestrian path is an important infrastructure that supporting pedestrian activities. A good pedestrian path will increase comfort, thus indirectly reducing dependence on motorized vehicle use. This study aims to evaluate the comfort of the condition of the pedestrian path in the area of Jl. Ratulangi - Jl. Permindo Kota Padang through a Climatic, Physical and Visual analysis approach. Descriptive statistical analysis techniques, perceptions and preferences analysis approaches were used. The validity and reliability test proved significant to the 12 question items given to 100 respondents. The results of the perception and preference analysis carried out to measure visual comfort prove that the category of Pedestrian Path is "quite comfortable" (57.73\%). The results of the analysis of climatic comfort at a temperature of $27.5 \mathrm{oC}$ and a humidity value of $68 \%$ with a THI value of 25.74 , indicate that the pedestrian path is in a comfortable condition. The results of the perception analysis show that currently the pedestrian path on Jl. Ratulangi - Jl. Permindo has functioned well (1) as a special pedestrian lane (2) as a space for the beauty of the city (3) as a waiting room for vehicles (4) as a space for socializing and (5) as a shelter. Things that still need attention on this route are air circulation (26\%) and safety on pedestrian paths (24\%). Perception analysis related to the reality aspect shows that the condition of the pedestrian path is too hot (27\%) and the large number of street vendors (26\%) are the main obstacles. The results of the preference analysis show that the comfort of the pedestrian paths in the Jl. Ratulangi - Jl. Permindo Kota Padang can be carried out by: (1) increasing the quantity of vegetation / canopy (48\%) (2) adding complementary facilities such as lights, benches and trash cans $(27 \%)$, (3) controlling the conversion of sidewalk functions (15\%) that are misused by street vendors and parking vehicles. (4) reduction of pollution / odor (10\%).
\end{abstract}

Keywords: Pedestrian Path, Climatic, Physical and Visual Comfortability, Perception and preference analysis.

\begin{abstract}
Abstrak
Jalur pedestrian merupakan salah satu infrastruktur yang penting dalam menunjang aktivitas pejalan kaki. Jalur pedestrian yang baik akan meningkatkan kenyamanan, sehingga secara tidak langsung menurunkan ketergantungan terhadap penggunanan kendaraan bermotor. Penelitian ini bertujuan untuk mengevaluasi kenyamanan Kondisi Jalur pedestrian kawasan Jl. Ratulangi - Jl. Permindo Kota Padang melalui pendekatan analisis klimatik dan visual. Digunakan teknik analisis statistik deskriptif dan pendekatan analisis persepsi dan preferensi. Uji Validitas dan Reliabilitas terbukti signifikan terhadap 12 item pertanyaan yang diberikan pada 100 responden. Hasil analisis persepsi dan preferensi yang dilakukan untuk mengukur kenyamanan visual membuktikan bahwa Jalur Pedestrian Kawasan Jalan Ratulangi sudah berada pada kategori cukup nyaman $(57,73 \%)$. Hasil analisis kenyamanan klimatik pada suhu $27,5^{\circ} \mathrm{C}$ dan nilai kelembaban $68 \%$ dengan nilai $\mathrm{THI}$ sebesar 25,74, menunjukkan bahwa jalur pedestrian tersebut dalam kondisi nyaman. Hasil analisis persepsi menunjukkan saat ini jalur pedestrian di Jl. Ratulangi - Jl. Permindo telah berfungssi dengan baik (1) sebagai jalur khusus pejalan kaki (2) sebagai ruang keindahan kota (3) sebagai ruang menunggu kendaraan (4) Sebagai ruang bersosialisasi dan (5) Sebagai ruang berteduh. Hal yang masih perlu menjadi perhatian di jalur ini adalah sirkulasi udara (26\%) dan keamanan di jalur pedestrian (24\%). Analisis persepsi terkait aspek kenyamaan menunjukkan bahwa kondisi jalur pedestrian yang terlalu panas (27\%) dan banyaknya pedagang kaki lima dengan (26\%) menjadi kendala utama. Hasil analisis preferensi menunjukkna bahwa peningkatan kenyamanan Jalur pedestrian kawasan Jl. Ratulangi - Jl. Permindo Kota Padang dapat dilakukan dengan: (1) peningktan kuantitas vegetasi/ kanopi (48\%) (2) penambahan fasilitas pelengkap seperti lampu, bangku dan tong sampah (27\%), (3) Penertiban alih fungsi
\end{abstract}

Informasi Artikel

Diterima Redaksi : 10-09-2020 | Selesai Revisi : 30-10-2020 | Diterbitkan Online : 31-10-2020 
trotoar (15\%) yang disalahgunakan oleh Pedagang Kaki Lima dan kendaraan parkir. (4) pengurangan polusi / bau tak sedap (10\%).

Kata kunci : Jalur Pedestrian, Kenyamanan Klimatik, Fisik dan Visual, Analisis persepsi dan preferensi.

\section{Pendahuluan}

Jalur pedestrian merupakan ruang pelayanan yang berfungsi untuk kegiatan pejalan kaki dalam melakukan aktivitas, sehingga dapat meningkatkan keamanan, kelancaran dan kenyamanan bagi pejalan kaki. Selain itu, jalur pedestrian juga tempat terjadinya interaksi sosial antar masyarakat. Kenyamanan jalur pedestrian secara langsung meningkatkan kuantitas pejalan kaki. Kenyamanan dapat Bentuk kenyamanan dapat berupa kenyamanan klimatik, fisik maupun visual. Kenyamanan fisik berkaitan dengan kesesuaian bentuk dan desain elemen fisik terhadap kondisi lingkungan di jalur pedestrian. Aspek fisik yang dimaksud meliputi aksessibilitas, lebar pedestrian, disain paving, bahan perkerasan, street furniture, vegetasi dan elemen fisik lainnya [1]. Kenyamanan visual berkaitan dengan kesesuaian pemandangan yang ditangkap oleh mata pengamat dengan lingkungannya melalui persepsi dan preferensi [2],[3].

Sedangkan kenyamanan klimatik berhubungan dengan persepsi manusia terhadap rasa panas dan dingin. Kenyamanan klimatik berhubungan pula dengan kesesuaian faktor iklim mikro yang mempengaruhi temperatur kulit yang meliputi, kelembaban, angin dan temperatur udara [2],[3]. Suhu yang nyaman dapat diwujudkan dengan memahami unsur-unsur tertentu [3],[4] diantaranya : (1).Unsur-unsur iklim mikro (angin, temperatur udara) yang dapat mempengaruhi kenyamanan suhu pada manusia. (2). Unsur-unsur lanskap (tanaman, air) yang mempengaruhi iklim mikro.

Di Indonesia jalur pedestrian Indonesia seringkali dilaporkan belum berfungsi secara optimal. Sebagian jalur trotoar telah beralih fungsi [5]. Trotoar tidak hanya dilalui oleh pejalan kaki, tetapi juga oleh kendaraan bermotor sehingga mengurangi kenyamanan pejalan kaki.

\section{Metode Penelitian}

Perhitungan jumlah sampel menggunakan aplikasi program Sample Size Calculator dari website Raosoft. Dilakukan analisis statistik menggunakan analysis toolpack dari Microsoft Excel 2007.

Metode analisis deskriptif dilakukan untuk menganalisis kenyamanan klimatik. Dilakukan pula teknik analisis persepsi dan preferensi untuk menganalisis kenyamanan fisik dan visual pengguna.

\section{Temperature Humidity Index}

Dalam anaisis kenyamanan klimatik, digunakan Temperature Humidity Index (THI). Temperature Humidity Index merupakan suatu indeks untuk menetapkan kenyamanan secara kuantitatif dengan menggunakan suhu dan kelembaban relatif udara [3] dengan rumus sebagai berikut: 


$$
\mathrm{THI}=0,8 \mathrm{Ta}+\frac{(\mathrm{RH} \times \mathrm{Ta})}{500}
$$

Dimana THI adalah Indeks Kenyamanan, Ta merupakan Suhu Udara $\left({ }^{\circ} \mathrm{C}\right)$ dan $\mathrm{RH}$ adalah Kelembaban Relatif Udara (\%)

\section{Analisis Persepsi dan Preferensi}

Defenisi Kenyamanan fisik dan visual pada penelitian ini meliputi kondisi fisik jalur pedestrian yang ditangkap secara visual oleh mata pengguna dan dinilai menurut perspektif pengguna jalur pedestrian. Dalam menganalisis Persepsi dan preferensi terkait kenyamanan fisisk dan visual, digunakan 12 instrumen variabel. Opsi pertanyaan disusun dalam bentuk kuisioner dan disebar pada 100 pengguna jalur pedestrian secara acak melalui teknik interview terstruktur.

Jawaban pertanyaan disusun atas 5 kriteria Interval kelas kenyamanan yakni; Sangat Nyaman (SN), Nyaman (N), Cukup Nyaman $(\mathrm{CN})$, Tidak Nyaman (TN), Sangat Tidak Nyaman (STN)

Tabel 1. Interval Kelas Kriteria Kenyamanan

\begin{tabular}{c|c}
\hline $\begin{array}{c}\text { Interval Kelas } \\
\text { Persentase (\%) }\end{array}$ & Kriteria \\
\hline $100-84$ & Sangat Nyaman (SN) \\
$80-60$ & Nyaman (N) \\
$60-40$ & Cukup Nyaman (CN) \\
$40-20$ & Tidak Nyaman (TN) \\
$0-20$ & Sangat Tidak Nyaman \\
& (STN) \\
\hline
\end{tabular}

Persentase Nilai persepsi dapat dihitung menggunakan rumus:

Kriteria $(\mathrm{SN}, \mathrm{N}, \mathrm{CN}, \mathrm{TN}, \mathrm{STN})=$

$$
\frac{\text { Countif Responden" }}{\text { Jumlah Responden }} \times 100 \%
$$

\section{Uji Validitas dan Reliabilitas}

Pengujian validitas konstruksi dilakukan dengan analisis faktor, yaitu dengan mengkorelasikan antara skor item instrumen dengan menggunakan Pearson Product Moment sebagai berikut:

$r$ hitung $=\frac{n\left(\sum X Y\right)-\left(\sum X\right) \cdot\left(\sum Y\right)}{\sqrt{\left\{n \cdot \sum X^{2}-\left(\sum X\right)^{2}\right\} \cdot\left\{n \cdot \sum Y^{2}-\left(\sum Y\right)^{2}\right\}}}$

Dimana $\mathrm{R}$ hitung adalah Koefisien Korelasi, $\sum X i$ adalah Jumlah Skor Item, $\sum Y i$ adalah Jumlah Skor Total item dan $\mathrm{N}$ adalah Jumlah Responden.

Selanjutnya dihitung nilai t dengan rumus:

$$
\text { thitung }=\frac{r \sqrt{n-2}}{1-r^{2}}
$$

Dimana $\mathrm{t}$ hitung adalah Nilai $\mathrm{t}$ hitung, $\mathrm{R}$ adalah Koefisien Korelasi hasil $r$ hitung dan $\mathrm{N}$ adalah Jumlah Responden.

Total varians butir $(S i)$ dan total $(S t)$ varians dihitung menggunakan persamaan berikut;

$$
s i=\frac{\sum X i^{2}-\frac{\left(\sum X i\right)^{2}}{N}}{N}
$$

Dimana Si adalah Varians Skor Tiap - Tiap Item, $\sum \mathrm{Xi}^{2}$ adalah Jumlah Kuadrat Item Xi, $\left(\sum \mathrm{Xi}\right)^{2}$ adalah Jumlah Item Xi Dikuadratkan, dan $\mathrm{N}$ adalah Jumlah Responden.

$$
S t=\frac{\sum X t^{2}-\frac{\left(\sum X t\right)^{2}}{N}}{N}
$$

Dimana St adalah Varians Total, $\sum \mathrm{Xt}^{2}$ adalah Jumlah Kuadrat $\mathrm{X}$ Total, $\left(\sum \mathrm{Xt}\right)^{2}$ adalah Jumlah $X$ Total Dikuadratkan, dan $\mathrm{N}$ adalah Jumlah Responden.

Selanjutnya dilakukan uji reliabilitas instrumen menggunakan Cronbach Alpha sebagai berikut:

$$
\mathrm{r}=\left[\frac{k}{(k-1)}\right]\left[1-\frac{\sum S i}{S t}\right]
$$

Dimana $\mathrm{R}$ adalah Koefisien Reliabilitas Instrument $(\propto), \mathrm{K}$ adalah Jumlah Item (Soal), $\sum$ Si adalah Jumlah Varians Skor Tiap - Tiap Item dan St = Jumlah Varians Total . 
Uji t dilakukan menggunakan Kriteria uji $\mathrm{t}$ sebagai berikut :

t hitung $>\quad t$ tabel berarti valid

t hitung $<\quad t$ tabel berarti tidak valid

Kriteria Uji Reliabilitas Instrumen

Jika $r$ hitung $>r$ tabel berarti Reliabel

Jika $r$ hitung $<r$ tabel berarti tidak Reliabel

\section{Hasil dan Pembahasan}

Berdasarkan hasil pengamatan dan analisis, jalur pedestrian Jl. Ratulangi - Jl. Permindo termasuk kategori layak. Menurut standar lebar jalur pedestrian pada jalan primer dengan lebar 2,75, disarankan jumlah pejalan kaki 3 orang dengan kecepatan pergerakkan 1,5 detik/meter [6]. Diamati lebar minumum jalur pedestrian di kawasan kajian 2,5 m untuk maksimal 3 orang.

\section{Analisa Temperature Humidity Index}

Berdasarkan data dari Badan Meteorologi Klimatologi dan Geofisika (BMKG) sepanjang tahun 2017 suhu di wilayah Kota Padang berkisar antara $26,3{ }^{\circ} \mathrm{C}-27,7{ }^{\circ} \mathrm{C}$ dengan kelembaban udara berkisar antara 71,3\% 80,1\%. Data kondisi Klimatik di wilayah Kota Padang selama tahun 2017 mulai Januari Oktober dapat dilihat pada tabel 2.

Tabel 2. Kondisi Klimatik di Wilayah Kota Padang, 2017

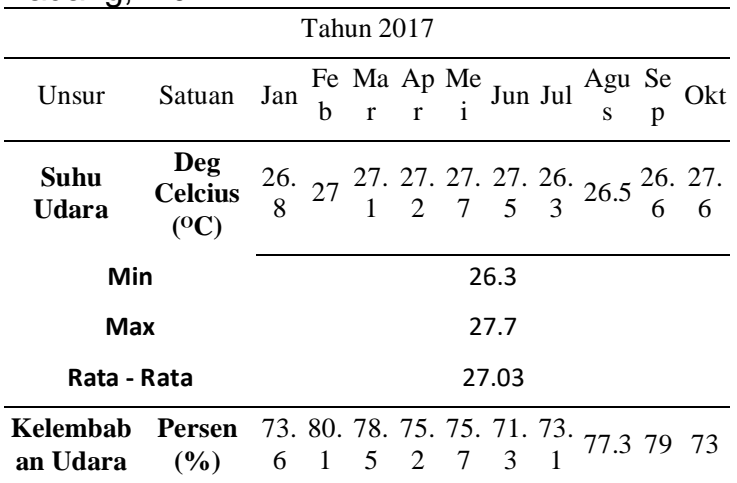

\begin{tabular}{cc}
\cline { 2 - 2 } Min & 71.3 \\
Max & 80.1 \\
Rata - Rata & 75.68 \\
\hline
\end{tabular}

Sumber : BMKG, Lokasi Pengukuran maritim : Stasiun aaaamaritim Teluk Bayur, Kota Padang (2017)

Data tersebut dianalisis untuk mendapatkan indeks suhu dan kelembaban Kota Padang dengan menggunakan persamaan (1) seperti terlihat pada Tabel 3.

Tabel 3. Temperature Humidity Index (THI)

\begin{tabular}{|c|c|c|}
\hline \multirow{2}{*}{\multicolumn{2}{|c|}{$\begin{array}{cc}\text { N } & \text { Kondisi Bio - } \\
\text { o } & \text { Fisik }\end{array}$}} & Tahun 2017 \\
\hline & & Jan Feb Mar $\underset{r}{\operatorname{Ap~}} \underset{i}{\operatorname{Me}}$ Jun Jul $\underset{\mathrm{u}}{\mathrm{Ag}} \underset{\mathrm{p}}{\mathrm{Se}}$ Okt \\
\hline
\end{tabular}

Temperature $\quad$ 25. 25.925 .9 25. 26. 25.9 24. 25. 25. 26.1

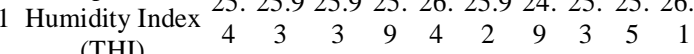

Analisis nilai Temperature Humidity Index (THI) pada Tahun 2017 menunjukkan kondisi klimatik di wilayah Kota Padang di bulan Januari Oktober berkisar antara 24,9-26,11 (Tabel 3). Dari hasil analisis nilai THI kondisi klimatik di wilayah Kota Padang di bulan Januari September tidak melampaui batas nyaman dan untuk bulan Oktober nilai THI > 26 .

Perhitungan kondisi klimatik di lokasi penelitian dilakukan dengan pengambilan Sampel suhu dan kelembaban relatif $(\mathrm{RH})$ menggunakan alat ukur thermo-hygro digital pada tanggal 10 Januari 2018. Interval waktu pengukuran dilakukan dalam 4 tahap; pagi hari dimulai dari pukul 08:00 - 11.00 wib , siang hari pada pukul 11.00 - 14.00 wib, sore pada pukul 14.00 17.00 wib, dan malam pada pukul $19.00-20.00$ wib.

Analisis Kenyamanan klimatik dihitung secara kuantitatif melalui pengukuran Temperature Humidity Index (THI) menggunakan persamaan (1). Hasilnya dapat dilihat pada Tabel 4. 
${ }^{1}$ Angelalia Roza, ${ }^{2}$ Sandri Artika Suri

Jurnal Ilmiah Rekayasa Sipil Vol . 17 No. 2 Edisi Oktober 2020

Tabel 4. Pengamatan Suhu dan Kelembaban Relatif terhadap Temperature Humidity Index

\begin{tabular}{|c|c|c|c|c|c|c|c|}
\hline \multirow{4}{*}{$\begin{array}{c}\text { Data } \\
\text { Lapangan }\end{array}$} & \multirow{3}{*}{$\begin{array}{c}\text { Pagi } \\
(08.00- \\
11.00)\end{array}$} & \multicolumn{5}{|c|}{ Waktu Pengambilan Data } & \multirow{4}{*}{$\begin{array}{c}\text { Rata - } \\
\text { Rata }\end{array}$} \\
\hline & & $\mathrm{Sia}$ & & & ore & Malam & \\
\hline & & $\begin{array}{r}(11 .) \\
14 .\end{array}$ & $00-$ & & $.00-$ & $\begin{array}{c}(19.00- \\
20.00)\end{array}$ & \\
\hline & Min Max & Min & Max & Min & $\operatorname{Max}$ & Min Max & \\
\hline & Pengukurar & n Send & iri* Ja & 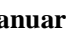 & i 2018 & & \\
\hline $\begin{array}{l}\text { Suhu } \\
\text { Udara }\left({ }^{\circ} \mathrm{C}\right)\end{array}$ & 24 & 29 & 30 & 30 & 29 & $26 \quad 25$ & 25.75 \\
\hline $\begin{array}{l}\text { Kelembab } \\
\text { an Udara } \\
(\%)\end{array}$ & 6062 & 72 & 65 & 67 & 70 & 7375 & 68 \\
\hline & 22.024 .94 & 27.37 & & 28.0 & & 24.523 .7 & 25.7412 \\
\hline THI & 8 & 6 & 27.9 & 2 & 27.26 & 96 & 5 \\
\hline
\end{tabular}

BMKG* Oktober 2017

\begin{tabular}{|c|c|c|c|c|c|c|c|c|}
\hline $\begin{array}{l}\text { Suhu } \\
\text { Udara }\left({ }^{\circ} \mathrm{C}\right)\end{array}$ & 26.3 & 27.2 & 27.2 & 27.727 .7 & 26.8 & 26.6 & 26 & 26.94 \\
\hline $\begin{array}{l}\text { n Udara } \\
\%)\end{array}$ & 71.3 & 78.5 & 78.5 & 80.180 .1 & 75.7 & 73.1 & 79 & 77.04 \\
\hline & 24.7 & & & 26.6 & & 25.1 & 24.9 & \\
\hline 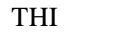 & & 26.03 & 26.03 & 026.6 & 25.5 & 7 & 1 & 25.70 \\
\hline
\end{tabular}

Hasil analisis perhitungan klimatik terkait suhu dan kelembababan menunjukkan bahwa jalur pedestrian Jl. Ratulangi - Jl. Permindo berada pada kondisi nyaman.

\section{Analisis Karakteristik responden}

Karakteristik pengguna jalur pedestrian Jl. Ratulangi - Jl. Permindo diwakili oleh variabel jenis kelamin, usia, pendidikan, dan pekerjaan. Seperti dilihat pada Tabel 5 .

Tabel 5. Karakteristik Responden

\begin{tabular}{|c|c|c|c|c|}
\hline No. & $\begin{array}{l}\text { Karakteristik } \\
\text { Responden }\end{array}$ & Kateg & & \\
\hline \multirow{2}{*}{1} & \multirow{2}{*}{ Jenis Kelamin } & Laki - Laki & $: 46$ & Resp \\
\hline & & Perempuan & $: 54$ & Resp \\
\hline \multirow{5}{*}{2} & \multirow{5}{*}{ Usia } & $<20$ Tahun & $: 45$ & Resp \\
\hline & & 20 - 30 Tahun & : 53 & Resp \\
\hline & & 31 - 40 Tahun & $: 2$ & Resp \\
\hline & & 41 - 50 Tahun & $: 0$ & Resp \\
\hline & & $>50$ Tahun & 0 & Resp \\
\hline
\end{tabular}

\begin{tabular}{ccc}
\hline & Tidak Kerja \& lainnya & $: 7$ Resp \\
$3 \quad$ Pekerjaan & Pelajar/Mahasiswa & $: 76$ Resp \\
& Pegawai Negri \& Swasta & $: 10$ Resp \\
& Wiraswasta & $: 10$ Resp \\
\hline \multirow{4}{*}{ Pendidikan } & Tidak Sekolah & $: 0$ Resp \\
& SD & $: 0$ Resp \\
& SMP & $: 2$ Resp \\
& SMA & $: 73$ Resp \\
& Perguruan Tinggi & $: 24$ Resp \\
& Lainnya & $: 1$ Resp \\
\hline
\end{tabular}

Responden yang dijumpai mayoritas berjenis kelamin perempuan (54\%). Responden merupakan pelajar/mahasiswa (76\%). Responden berada pada rentang usia $<20$ Tahun (45\%) dan usia antara 20 - 30 Tahun (53\%). Responden berpendidikan Sekolah Menengah Atas (73\%) dan sarjana (24\%).

\section{Analisis Persepsi}

Penilaian aspek kenyamanan fisik dan visual terhadap kondisi jalur pedestrian di Jl. Ratulangi - JI. Permindo dilakukan melalui analisis persepsi dan preferensi. Persepsi responden terkait fungsi jalur pedestrian tersebut direkapitulasi seperti terlihat pada Tabel 6 .

Tabel 6. Persepsi Fungsi Jalur Pedestrian

\begin{tabular}{llc}
\hline No & \multicolumn{1}{c}{ Persepsi Fungsi Jalur Pedestrian } & $\begin{array}{c}\text { Jumlah } \\
\text { (Resp) }\end{array}$ \\
\hline 1 & $\begin{array}{l}\text { Berfungsi sebagai jalur khusus bagi } \\
\text { pejalan kaki }\end{array}$ & $\mathrm{u} 99$ \\
2 & $\begin{array}{l}\text { Berfungsi sebagai Ruang menunggu } \\
\text { kendaraan }\end{array}$ & 80 \\
3 & $\begin{array}{l}\text { Berfungsi sebagai Ruang bersosialisasi } \\
4\end{array}$ & 79 \\
& $\begin{array}{l}\text { Berfungsi sebagai Ruang berteduh } \\
\text { Berfungsi sebagai Ruang keindahan } \\
\text { kota }\end{array}$ & 75 \\
6 & $\begin{array}{l}\text { Berfungsi sebagai Ruang untuk } \\
\text { pedagang kaki lima (PKL) }\end{array}$ & 38 \\
7 & Berfungsi sebagai Ruang tempat Parkir & 34 \\
\hline
\end{tabular}

Informasi Artikel

Diterima Redaksi : 10-09-2020 | Selesai Revisi : 30-10-2020 | Diterbitkan Online : 31-10-2020 
Berdasarkan hasil analisis data persepsi responden, jalur pedestrian di Jl. Ratulangi - Jl. Permindo telah berfungssi dengan baik (1) sebagai jalur khusus pejalan kaki (2) sebagai ruang keindahan kota (3) sebagai ruang menunggu kendaraan (4) Sebagai ruang bersosialisasi dan (5) Sebagai ruang berteduh.

Pengukuran indeks kriteria kenyamanan ruang pedestrian dilakukan dengan pendekatan statistik deskriptif melibatkan 12 item variabel yang direkapitulasi pada Tabel 6 berikut. Nilai total skor persepsi yang diperoleh adalah 3464 dalam skala 6000 . Sehingga melalui persamaan (1) dapat diketahui kriteria Kenyamanan di jalur pedestrian Jl. Ratulangi Jl. Permindo berada Pada kategori cukup nyaman $(57,73 \%)$ seperti terlihat pada Tabel 7 berikut.

Tabel 7. Rekapitulasi Skor Aspek Kenyamanan

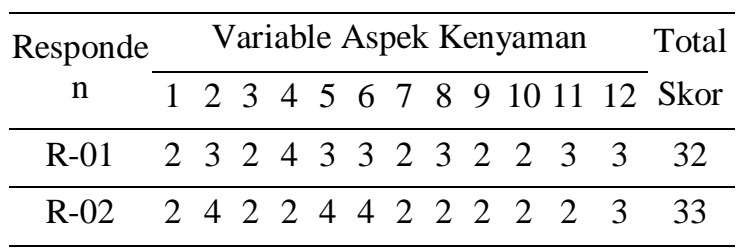

\begin{tabular}{cccccccccccccc} 
R-99 & 3 & 3 & 2 & 3 & 3 & 3 & 3 & 3 & 3 & 3 & 3 & 3 & 35 \\
R-100 & 1 & 4 & 3 & 2 & 5 & 4 & 5 & 4 & 3 & 4 & 4 & 4 & 43 \\
\hline
\end{tabular}

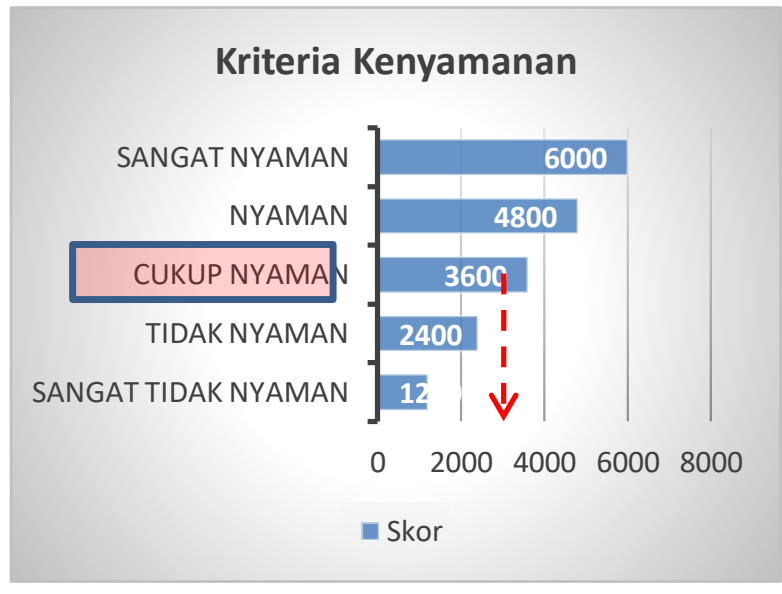

Gambar 1. Interpretasi Skor terhadap Interval Kenyamanan

\section{Analisis Validitas dan Reliabilitas Insturmen}

Uji validitas instrument dilakukan menggunakan Pearson Pruduct Moment (persamaan 3) seperti terlihat pada Tabel 8 berikut.

Tabel 8. Perhitungan Korelasi

\begin{tabular}{cccccc}
\hline \multicolumn{6}{c}{ Item Pertanyaan No 1. } \\
\hline No & $\mathrm{X}$ & $\mathrm{Y}$ & $\mathrm{X}^{2}$ & $\mathrm{Y}^{2}$ & $\mathrm{XY}$ \\
\hline R-01 & 2 & 32 & 4 & 1024 & 64 \\
R-02 & 2 & 32 & 4 & 1089 & 66 \\
\hline \multirow{2}{*}{ dst } & & & & & \\
\cline { 2 - 5 } & & & & & \\
\hline R-99 & 3 & 35 & 9 & 1225 & 66 \\
R-100 & 1 & 43 & 1 & 1849 & 105 \\
\hline \multirow{2}{*}{ Jumlah } & $\Sigma \mathrm{X}$ & $\Sigma \mathrm{Y}$ & $\Sigma \mathrm{X}^{2}$ & $\Sigma \mathrm{Y}^{2}$ & $\Sigma \mathrm{XY}$ \\
\cline { 2 - 6 } & 244 & 3464 & 676 & 123422 & 8648 \\
\hline
\end{tabular}

Dilakukan perhitungan nilai korelasi setiap butir pertanyaan menggunakan persamaan (4) sebagai berikut:

$r$ hitung

$$
\begin{aligned}
& =\frac{100(8648)-(244) \cdot(3464)}{\sqrt{\left.100\{(676)-244)^{2}\right\} \cdot\left\{100 \cdot(123422)-(3464)^{2}\right\}}} \\
& =0,372
\end{aligned}
$$


${ }^{1}$ Angelalia Roza, ${ }^{2}$ Sandri Artika Suri

Jurnal Ilmiah Rekayasa Sipil Vol . 17 No. 2 Edisi Oktober 2020

Selanjutnya dilakukan perhitungan nilai $t$ menggunakan persaaman (5)

$$
\text { thitung }=\frac{0,372 \sqrt{100-2}}{\sqrt{1}-0,372^{2}}=3,967
$$

Nilai $\mathrm{t}$ tabel $=1.66055$ pada signifikasikan $\alpha=$ 0,05 dan $\mathrm{dk}=100-2=98$. Menurut kriteria uji $\mathrm{t}$ (persamaan 8) semua item pertanyaan dinilai valid ( Tabel 9).

Selanjutnya dilakukan uji reliabilitas instrumen menggunakan Cronbach Alpha dengan terlebih dahulu menghitung total varians butir $(S i)$ dengan persamaan (5) dan total (St) varians dengan persamaan (6).

Selanjutnya nilai $r$ dihitung menggunakan Persamaan (7)

$r=\left[\frac{12}{(12-1)}\right]\left[1-\left(\frac{9.006}{34.2904}\right)\right]=0.804$

Nilai $r$ hitung $=0.804$ sedangkan nilai tabel $r$ table Product Moment; $\mathrm{dk}=\mathrm{N}-1=99$ pada level signifikasikan 5\%, adalah 0.196. Menurut kriteria uji reliabilitas instrumen menggunakan Cronbach Alpha (Persamaan 9) dinyatakan bahwa data 100 responden yang dianalisis terhadap 12 item pertanyaan adalah Reliabel ( Tabel 9).

Tabel 9. Hasil Uji Validitas dan Reliabilitas

\begin{tabular}{llccc}
\hline $\begin{array}{l}\mathrm{N} \\
\mathrm{o}\end{array}$ & Kondisi Jalur Pedestrian & $\begin{array}{c}\text { Koefisien } \\
\text { Korelasi } \\
\text { (r.hitung) }\end{array}$ & $\begin{array}{c}\text { Harga } \\
\text { (t.hitung) }\end{array}$ & Hasil \\
\hline 1 & Terik Matahari & 0.372 & 3.967 & Valid \\
2 & Pemandangan & 0.565 & 6.778 & Valid \\
3 & Kebisingan Kendaraan & 0.478 & 5.387 & Valid \\
4 & Aroma Tidak Sedap & 0.471 & 5.285 & Valid \\
5 & Kebersihan & 0.674 & 9.032 & Valid \\
6 & Keindahan & 0.703 & 9.785 & Valid \\
& Kelengkapan Fasilitas & & & \\
7 & Pendukung Kenyamanan & 0.592 & 7.272 & Valid \\
8 & Keamanan dari kendaraan & 0.715 & 10.124 & Valid \\
9 & Keamanan dari Kejahatan & 0.651 & 8.49 & Valid \\
10 & Bentuk dan Kualitas jalur & 0.467 & 5.228 & Valid
\end{tabular}

11 Kejelasan Sirkulasi Jalur

$0.509 \quad 5.854 \quad$ Valid

12 Aksebilitas Jalan

$0.599 \quad 7.405 \quad$ Valid

Tabel 10. Persepsi Kenyamanan Responden terkait 12 instrumen variabel

\begin{tabular}{|c|c|c|c|c|c|c|}
\hline $\begin{array}{l}\mathrm{N} \\
\mathrm{O}\end{array}$ & Kondisi Jalur Pedestrian & $\mathrm{SN}$ & $\mathrm{N}$ & $\mathrm{CN}$ & $\mathrm{TN}$ & STN \\
\hline & Terik Matahari & 4 & 10 & 16 & 45 & 47 \\
\hline 2 & Pemandangan & 4 & 24 & 53 & 23 & 0 \\
\hline 3 & Kebisingan Kendaraan & 1 & 4 & 16 & 56 & 34 \\
\hline 4 & Aroma Tidak Sedap & 2 & 7 & 21 & 50 & 41 \\
\hline 5 & Kebersihan & 4 & 24 & 43 & 20 & 16 \\
\hline 6 & Keindahan & 12 & 27 & 45 & 12 & 9 \\
\hline 7 & $\begin{array}{l}\text { Kelengkapan Fasilitas } \\
\text { Pendukung Kenyamanan }\end{array}$ & 10 & 33 & 45 & 19 & 15 \\
\hline 8 & Keamanan dari kendaraan & 4 & 37 & 34 & 17 & 6 \\
\hline & Keamanan dari Kejahatan & 1 & 17 & 24 & 33 & 51 \\
\hline & 0 Bentuk dan Kualitas jalur & 3 & 43 & 26 & 15 & 15 \\
\hline & 1 Kejelasan Sirkulasi Jalur & 2 & 16 & 47 & 30 & 7 \\
\hline & 2 Aksebilitas Jalan & 2 & 33 & 52 & 9 & 5 \\
\hline
\end{tabular}

Kondisi jalur pedestrian yang mempengaruhi persepsi kenyamanan responden secara detail dapat diamati melalui 12 instrumen variabel seperti terlihat pada Tabel 10

Pada pengamatan di sepanjang lokasi penelitian Jl. Ratulangi - Jl. Permindo, ruang pejalan kaki tidak terlindung/tidak beratap. Pejalan kaki dapat melakukan kegiatan berjalan kaki sambil melihat barang dagangan pada etalase toko di sepanjang jalur pedestrian. Penilaian persepsi kenyamanan responden terhadap kondisi jalur pedestrian tersebut erat kaitannya dengan: sirkulasi yang baik (26\%), keamanan (24\%) keteduhan (23\%), kebersihan yang baik (22\%) dan aroma (bau) $(5 \%)$ seperti terlihat pada Gambar 2. 


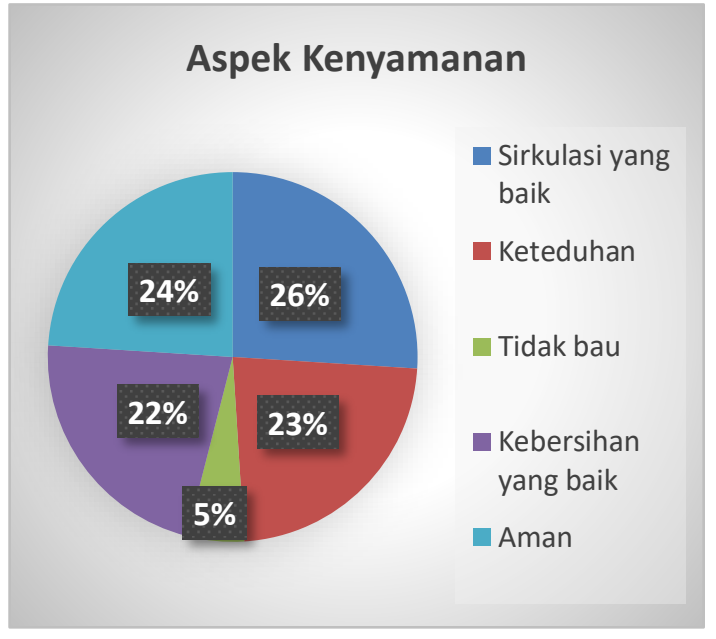

Gambar 2. Aspek Kenyamanan Jalur Pedestrian

Sedangkan aspek ketidaknyamanan menurut persepsi responden berkaitan dengan variabel: cuaca yang terlalu panas sebanyak (27\%), penggunaan trotoar oleh pedagang kaki lima (PKL) (26\%), adanya Parkir liar (16\%), adanya bau tidak sedap (15\%), Banyak pengamen $(10 \%)$ dan Kurangnya fasilitas penyebrangan (6\%) seperti terlihat pada Gambar 3.

Jalur pedestrian JI. Ratulangi - Jl. Permindo ini dianggap kurang nyaman karena trotoar di jalur pedestrian tersebut masih dilewati kendaraan bermotor. Dengan adanya parkir ilegal, terjadilah pengalihan fungsi trotoar yang seharusnya hanya dikhususkan bagi pejalan kaki. Hal ini merupakan indikasi terjadinya gangguan permanen pada jalur trotoar [7] yang dapat menurunkan kenyamanan pejalan kaki dan tentu berpengaruh pula terhadap safety di jalur tersebut.

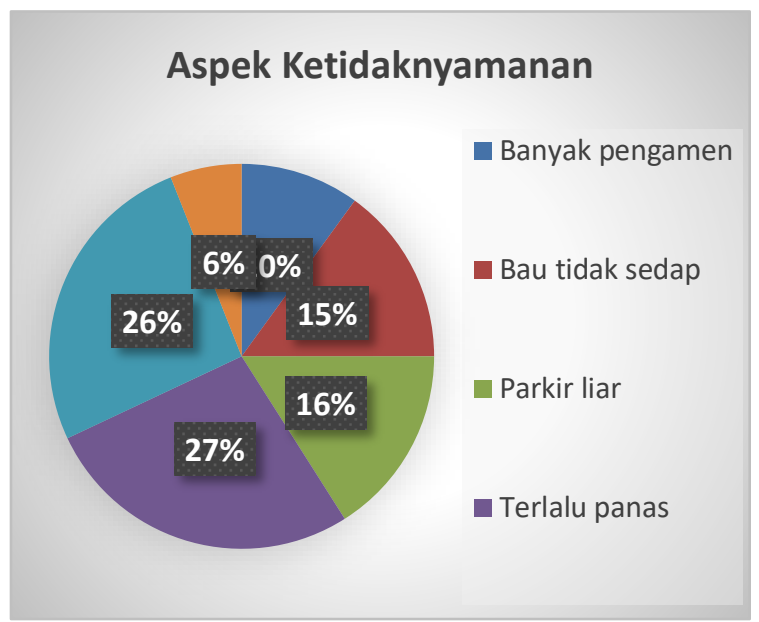

Gambar 3. Aspek Ketidaknyamanan Jalur Pedestria

\section{Analisis Preferensi responden}

Berdasarkan hasil analisis preferensi (Tabel 11) pengembangan jalur pedestrian Jl. Ratulangi Jl. Permindo diharapkan memenuhi fungsinya yaitu (1) sebagai jalur khusus pejalan kaki (2) sebagai ruang keindahan kota sebanyak dan (3) sebagai ruang berteduh sebanyak (4) sebgai Ruang menunggu kendaraan.

Tabel 11. Preferensi Pengembangan fungsi Jalur pedestrian

\begin{tabular}{llc}
\hline No & \multicolumn{1}{c}{ Fungsi Jalur Pedestrian } & $\begin{array}{c}\text { Jumlah } \\
\text { (Resp) }\end{array}$ \\
\hline 1 & $\begin{array}{l}\text { Berfungsi sebagai jalur khusus bagi } \\
\text { pejalan kaki }\end{array}$ & 100 \\
2 & $\begin{array}{l}\text { Berfungsi sebagai Ruang menunggu } \\
\text { kendaraan }\end{array}$ & 81 \\
3 & $\begin{array}{l}\text { Berfungsi sebagai Ruang bersosialisasi } \\
4\end{array}$ & 75 \\
5 & $\begin{array}{l}\text { Berfungsi sebagai Ruang berteduh } \\
\text { kota }\end{array}$ & 88 \\
6 & $\begin{array}{l}\text { Berfungsi sebagai Ruang untuk } \\
\text { pedagang kaki lima (PKL) }\end{array}$ & 27 \\
7 & \begin{tabular}{l} 
Berfungsi sebagai Ruang tempat Parkir \\
\hline
\end{tabular} & 20 \\
\hline
\end{tabular}

Hasil analisis preferensi (Gambar 4) menunjukkan bahwa peningkatan kenyamanan 
Jalur pedestrian kawasan Jl. Ratulangi - Jl. Permindo Kota Padang dapat dilakukan melalui 3 upaya (1) dengan peningktan kuantitas vegetasi/ kanopi (48\%) (2) meningkatkan fasilitas seperti lampu, bangku dan tong sampah (27\%) dan (3) penertiban alih fungsi trotoar (15\%).

Dalam upaya pengembangan jalur pedestrian rekomendasi peningkatan kuantitas vegetasi/ kanopi (48\%) dapat meningkatkan kenyamanan klimatik, sehingga dapat memenuhi fungsi jalur pedestrian sebagai ruang berteduh (Tabel 12).

Di sepanjang Jl. Ratulangi - Jl. Permindo banyak dijumpai aktivitas menunggu moda. Maka penyediaan fasilitas seperti lampu, bangku dan tong sampah (27\%) dapat meningkatkan kenyamanan fisisk dan visual pengguna, sehingga jalur pedestrian tersebut dapat berfungsi sebagai ruang keindahan kota. Sekaligus, memberi ruang bagi pejalan kaki untuk berhenti, beristirahat, duduk santai, menunggu dan juga bersosialisasi, sehingga harapan pengguna bahwa jalur pedestrian dapat berfungsi sebagai Ruang menunggu kendaraan dapat dipenuhi.

Harapan pengguna terkait fungsi jalur pedestrian yaitu sebagai jalur khusus pejalan kaki hendaknya direalisasikan dengan penertiban alih fungsi trotoar (15\%) yang disalahgunakan oleh Pedagang Kaki Lima dan kendaraan parkir.

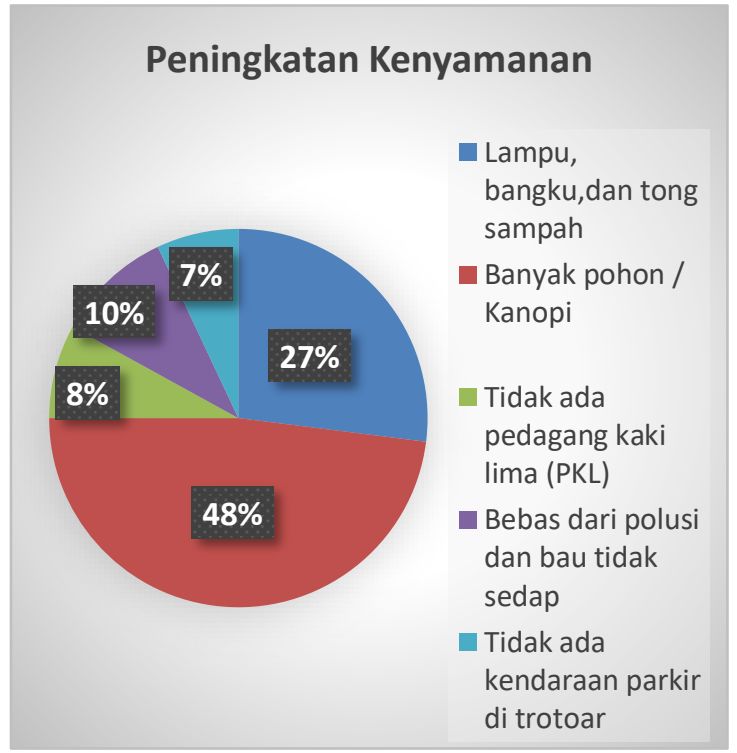

Gambar 4. Peningkatan kenyamanan Jalur Pedestrian

\section{Kesimpulan}

Dari penelitian ini dapat disimpulkan beberapa hal, seperti:

1. Kawasan JI. Ratulangi - Jl. Permindo sudah memiliki jalur pedestrian yang sesuai dengan standar minimum jalur pedestrian di perkotaan mengacu Pedoman Badan Standardisasi Nasional (BSN) No. 8 Tahun 2000.

2. Analisis perhitungan klimatik terkait suhu dan kelembababan menunjukkan bahwa jalur pedestrian Jl. Ratulangi - Jl. Permindo berada pada kondisi nyaman. Nilai suhu udara adalah $27,5^{\circ} \mathrm{C}$ dan nilai kelembaban adalah $68 \%$ dengan $\mathrm{THI}$ sebesar 25,74.

3. Analsis Persepsi terkait kenyamanan jalur pedestrian telah dievaluasi secara deskriptif melalui 12 opsi pertanyaan (kuesioner). Disimpulkan bahwa jalur pedestrian di Jl. Ratulangi - Jl. Permindo berada pada kategori cukup nyaman $(57,73 \%)$.

3. Jalur pedestrian Jl. Ratulangi - Jl. Permindo telah memenuhi fungsi utamanya (1) sebagai jalur khusus pejalan kaki (2) sebagai ruang 
keindahan kota (3) sebagai ruang menunggu kendaraan (4) Sebagai ruang bersosialisasi dan (5) Sebagai ruang berteduh.

5. Faktor ketidaknyamanan yang perlu menjadi perhatian utama yaitu (1) kondisi jalur pedestian yang terlalu panas (27\%) dan (2) banyaknya pedagang kaki lima di jalur pedestrian (26\%).

6. Upaya yang penting untuk dilakukan dalam meningkatkan kenyamanan, menurut persepsi responden adalah (1) pengaturan sirkulasi udara yang baik (26\%) dan pen yediaan jalur pedestrian yang aman (24\%).

\section{Saran}

Upaya peningkatan kenyamanan hendaknya diimbangi dengan kesadaran masyarakat sebagai pengguna agar tetap menjaga fasilitas di jalur pedestrian.

\section{Daftar Rujukan}

[1] Ikhsani, L. N., and Khadiyanta, P., F2015. User's Perception Towards Pedestrian Facility at Pemuda Street Magelang City, RUANG, Vol. 1 No. 3, 2015, 111-120, http://ejournal2.undip.ac.id/index.php/ruan $g$

[2] Marsh, (1991). Jenis-Jenis Aspek Kenyamanan.

[3] Khuluk,N (2016), Kajian Aspek Kenyamanan Terhadap Pengguna Ruang Pedestrian Ditinjau Dari Presepsi Dan Preferensi (Studi Kasus Jendral Sudirman Jakarta), Jurnal ilmiah ARJOUNA, Vol. 01, No.01 Oktober 2016.

[4] Irwan, S.N.R., \& Kaharuddin ( 2010), Studi Kenyamanan Untuk Aktivitas di Lanskap Hutan Kota UGM, Studi Kasus: Klaster Agro UGM, Jurnal IImu Kehutanan, Volume IV No. 2-- Juli-September 2010

[5] Roza, A., Fikri, A., \& Rusli, A. M. (2020). Analisis Kenyamanan Jalur Pedestrian Jalan Ps. Baru Kota Padang dengan Teknik Analisis Deskriptif Kualitatif. CIVED
(Journal of Civil Engineering and Vocational Education), Vol. 7. No 2, 2020.

[6] Pedoman Badan Standardisasi Nasional (BSN) No. 8 Tahun 2000, Pedoman Penyediaan dan Pemanfaatan Prasarana dan Sarana Ruang Pejalan Kaki di Perkotaan, Gugus Kerja Bidang Penataan Ruang Permukiman, Indonesia.

[7] Rahmi, H.M., \& Khadiyanta, P., 2018. Kajian Kualitas dan Tingkat Pelayanan Jalur Pedestrian di Koridor Jalan Khatib Sulaiman Kota Padang, Teknik PWK (Perencanaan Wilayah Kota) Vol 7(4), 2018, 223-232, http://ejournal3.undip.ac.id/index.php/pwk

Informasi Artikel

Diterima Redaksi : 10-09-2020 | Selesai Revisi : 30-10-2020 | Diterbitkan Online : 31-10-2020 